\title{
Problems of livestock reproduction with a focus on climate change
}

\author{
Roman Mylostyvyi ${ }^{\mathrm{a}}$ and Olena Izhboldina ${ }^{\mathrm{a}}$ \\ aDnipro State Agrarian and Economic University, S. Efremov St. 25, 49600, Dnipro, Ukraine.
}

ABSTRACT Climate change in the context of livestock reproduction is primarily associated with the heat stress (HS) adverse effect on livestock fertility. In females, during periods of heat, disorders of the reproductive tract occur, the placental nutrition of the fetus and its development are affected, while in males, spermatogenesis is damaged. Reproductive technologies and reproduction management are promising mitigation measures. Some other factors can also adversely affect the reproductive function in animals. The purpose of this study to show the current state of livestock reproduction, paying special attention to the problems associated with global climate change.

KEYWORDS animal reproduction, heat stress, reproductive disorders

Accepted March 23, 2021 Published online April 15, 2021

Cite this article: Mylostyyi and Izhboldina (2021) Problems of livestock reproduction with a focus on climate change. Multidisciplinary Reviews 4: e2021011. DOI: 10.29327/multi.2021011

\section{Introduction}

Decreasing yields and plant nutrient value as a natural fodder base for livestock, favourable environment for the pathogenic bacteria developing and spreading, as well as the direct effect of high temperatures on animal welfare are the causes of significant losses in livestock worldwide associated with climate change (Laporta et al 2020). On the other hand, long-term selection for high milk yield has led to limited oestrus in modern dairy cattle compared to the animals studied by researchers 40 years ago (Sheldon et al 2011). As many as half of the cows cannot produce the first dominant follicle in the postpartum period, numerous animals have abnormal oestrus with anovulatory anoestrus, cystic ovarian disease, or prolonged luteal phase, primarily due to various stressors (Lees et al. 2019). This requires comprehension of the current state of the problem and possible mitigation strategies. With this importance in mind, this mini-review article aimed at lighting the harmful effects of high temperatures on the reproductive function of animals and possible mitigation options.

\section{High-temperature effect}

A decline in cow insemination efficiency in recent decades is associated with the increase in average and maximum temperatures and reduced rainfall (Borş et al 2019). Heat stress (HS) is a major problem. With the temperature and humidity index (THI) increasing by one unit above 70 during the heat, the percentage of fertilization decreases by $4.6 \%$ (Krishnan et al 2017). HS's negative effects in late pregnancy became apparent in the offspring from generation to generation (the impact of transmission across at least two generations). There was a decrease in daughters and granddaughters' daily milk yield and a reduction in their productive life in the herd. The United States' losses run into hundreds of millions of dollars per year (Laporta et al 2020). However, this is not a critical issue for the middle-yielding cows in a moderately continental climate of Europe (Borş et al 2019).

The last weeks before parturition condition further productivity of dairy cattle. In late pregnancy, HS slowed the lacteous gland's involution in the first half of the interlactation period and delays the proliferation of lacteous gland cells before parturition (Ouellet et al 2020). Reduced productivity in goats is associated with HS's effect in late pregnancy Hooper et al (2020). It is the reduction of lacteous gland cells and inhibition of prolactin signal transmission in a cell. 
Heifers under prenatal HS conditions had lower weight, impaired metabolism, and immune function (Dado-Senn et al 2020).

Genome study in Holstein cows (Sigdel et al 2020) allowed identifying at least six portions associated with fertilization under HS conditions, directly involved in reproductive function and cellular response to HS. Such studies indicate possible genomic strategies in improving thermotolerance and fertility using selection markers.

\section{Changes in female reproductive tracts and fetal abnormalities}

Anovulation is a major cause of infertility and a severe reproductive disorder in female mammals. In many cases, infertility is associated with impaired luteinization of granulosa cells or thecal cells, threatening progesterone production (Abedel-Majed et al 2019). Under high temperatures conditions, nucleoli were fragmented in granulosa cells (Sirotkin et al 2021), they released less progesterone, not least because of impaired response to FSH. There were changes in follicular fluid components and inflammatory mediators' growth in preovulatory follicles (Rispoli et al 2020). The deficiency of nutrients supplied through the placenta was the cause of weight loss in new-born calves, impaired immune function, and disease susceptibility. Exposure to HS in calves in the womb may result in a low yield in adulthood due to impaired DNA methylation in the liver and lacteous gland tissue (Ouellet et al 2020). However, it has been reported (Ahmed et al 2017) that in late pregnancy, HS conditions in the womb had increased thermotolerance in the offspring in later periods of their development through the enhanced ability to dissipate heat to maintain the internal body temperature.

\section{Abnormalities in male breeders}

In the summer, sperm abnormalities became more frequent (Zaher et al 2020). There was a significant increase in total defects and the number of dead spermatozoids in male sheep, with a decrease in overall sperm motility and concentration; narrowing the diameter of the external epididymal tail duct caused azoospermia (El-Zeftawy et al 2020).

The mechanisms of maintaining the temperature in the scrotum are impaired in heat stress conditions (Wallage et al 2017). The period of spermatogenesis recovery after the heat exposure can be delayed up to eight weeks, but it can often take up the full spermatogenesis cycle. Moreover, the scrotum's ability to maintain the optimal temperature for spermatogenesis during HS periods (Lees et al 2019) has not been identified enough.

\section{Reproductive diseases}

Almost half of the clinical diseases in high-yielding dairy cows occur within three weeks after parturition (Vallejo et al 2019). Cows with metritis in the early postpartum period are in a state of significant oxidative stress (Mikulková et al 2020). The use of metabolic tests and assessment of cow body condition may be informative for preventing postpartum diseases under HS conditions one week after parturition (Torres et al 2020).

Infertility in dairy cattle is associated with pathogenic bacteria in the uterus even a few months after parturition. There have been reports (Horlock et al 2020) that after intrauterine infusions of pathogenic bacteria in the endometrium to heifers (Escherichia coli, Trueperella pyogenes) experimentally, the pathological changes in the transcriptome of endometrial cells, oviduct, and granulosa cells have been revealed even three months upon slaughter. Intrauterine ozone therapy, which was carried out 35 days after parturition (Escandón et al 2020), prevented subclinical endometritis and improved reproductive performance in dairy cows.

\section{Animal reproduction management}

The knowledge accumulated over the years about the reproductive system functioning and the proper use of hormonal drugs allows control of the ovary cycle of cows in reproductive management and cows insemination without detecting cows in heat (Vallejo et al 2019), as well as the use of ovulation synchronization protocols in numerous types of ovarian dysfunction as a therapeutic method (Nowicki et al 2017). 
Timely detection of animals in heat can significantly increase reproductive performance. Marques et al (2020) report a higher probability of cow fertilization after the first insemination due to a device for automatic detection of oestrus. According to other reports (Pereira et al 2020), the activity and rumination monitoring system also provided promising results in detecting oestrus in pasture conditions.

Reproductive technologies are widely used to maintain fertility in conditions of ever-increasing weather variability. Despite the revolutionary advances in embryo transplantation and continuous improvement of this method, Brazilian researchers are convinced of the need for further effective cooperation of practicing veterinarians and scientists (Rodrigues 2014). The enormous potential of ovaries in terms of producing viable follicles for insemination is still not being used. Attempts have been made to cultivate cow oocytes in vitro at certain development stages; however, no effective and reliable protocols have been developed so far (Barros et al 2020).

\section{Final considerations}

Understanding the mechanisms of high-temperature adverse effects on productive animals' reproductive function will allow developing mitigation strategies. The development of reproductive technologies and preventive managerial decisions will bear fruit under any climate change scenario.

\section{Conflict of interest statement}

The authors declare that there is no conflict of interest.

\section{Funding}

This work was supported by the Ministry of Education and Science of Ukraine (grant number 1439, December 22, 2018).

\section{References}

Abedel-Majed MA, Romereim SM, Davis JS, Cupp AS (2019) Perturbations in Lineage Specification of Granulosa and Theca Cells May Alter Corpus Luteum Formation and Function. Frontiers in Endocrinology 10. doi: 10.3389/fendo.2019.00832

Ahmed BMS, Younas U, Asar TO, Dikmen S, Hansen PJ, Dahl GE (2017) Cows exposed to heat stress during fetal life exhibit improved thermal tolerance. Journal of Animal Science 95:3497. doi: 10.2527/jas2016.1298

Barros RG, Lodde V, Franciosi F, Luciano AM (2020) In Vitro Culture Strategy for Oocytes from Early Antral Follicle in Cattle. Journal of Visualized Experiments 161. doi: 10.3791/61625

Borş S-I, Ibănescu I, Balla E, Borş A (2019) Changes in climate conditions and their effects on production and reproduction of medium yielding cows in temperate continental climate. Mljekarstvo 69:264-275. doi: 10.15567/mljekarstvo.2019.0406

Dado-Senn B, Laporta J, Dahl GE (2020) Carry over effects of late-gestational heat stress on dairy cattle progeny. Theriogenology 154:17-23. doi: 10.1016/j.theriogenology.2020.05.012

El-Zeftawy M, Mahmoud GB, Hassan M (2020) Impact of thermal stress exposure on seminal quality, antioxidant defence system, TNF- $\alpha$ and TIMP-3 in Ossimi ram. Reproduction in Domestic Animals 55:870-881. doi: 10.1111/rda.13697

Escandón BM, Espinoza JS, Perea FP, Quito F, Ochoa R, López GE, Galarza DA, Garzón JP (2020) Intrauterine therapy with ozone reduces subclinical endometritis and improves reproductive performance in postpartum dairy cows managed in pasture-based systems. Tropical Animal Health and Production 52:2523-2528. doi: 10.1007/s11250-020-02298-3

Fodor I, Lang Z, Ózsvári L (2020) Relationship of dairy heifer reproduction with survival to first calving, milk yield and culling risk in the first lactation. Asian-Australasian Journal of Animal Sciences 33:1360-1368. doi: 10.5713/ajas.19.0474

Hooper HB, Silva P dos S, de Oliveira SA, Meringhe GKF, Lacasse P, Negrão JA (2020) Effect of heat stress in late gestation on subsequent lactation performance and mammary cell gene expression of Saanen goats. Journal of Dairy Science 103:1982-1992. doi: $10.3168 /$ jds.2019-16734

Horlock AD, Piersanti RL, Ramirez-Hernandez R, Yu F, Ma Z, Jeong KC, Clift MJ D, Block J, Santos JEP, Bromfield JJ, Sheldon IM (2020) Uterine infection alters the transcriptome of the bovine reproductive tract three months later. Reproduction 160:93-107. doi: 10.1530/rep-19-0564 
Krishnan G, Bagath M, Pragna P, Vidya MK, Aleena J, Archana PR, Sejian V, Bhatta R (2017) Mitigation of the Heat Stress Impact in Livestock Reproduction. Theriogenology. doi: 10.5772/intechopen.69091

Laporta J, Ferreira FC, Ouellet V, Dado-Senn B, Almeida AK, De Vries A, Dahl GE (2020) Late-gestation heat stress impairs daughter and granddaughter lifetime performance. Journal of Dairy Science 103:7555-7568. doi: 10.3168/jds.2020-18154

Lees AM, Sejian V, Wallage AL, Steel CC, Mader TL, Lees JC, Gaughan JB (2019) The Impact of Heat Load on Cattle. Animals 9:322. doi: 10.3390/ani9060322

Marques O, Veronese A, Merenda VR, Bisinotto RS, Chebel RC (2020) Effect of estrous detection strategy on pregnancy outcomes of lactating Holstein cows receiving artificial insemination and embryo transfer. Journal of Dairy Science 103:6635-6646. doi: $10.3168 /$ jds.2019-17892

Mikulková K, Kadek R, Filípek J, Illek J (2020) Evaluation of oxidant/antioxidant status, metabolic profile and milk production in cows with metritis. Irish Veterinary Journal 73. doi: 10.1186/s13620-020-00161-3

Nowicki A, Barański W, Baryczka A, Janowski T (2017) OvSynch protocol and its modifications in the reproduction management of dairy cattle herds - an update. Journal of Veterinary Research 61:329-336. doi: 10.1515/jvetres-2017-0043

Ouellet V, Laporta J, Dahl GE (2020) Late gestation heat stress in dairy cows: Effects on dam and daughter. Theriogenology 150:471479. doi: 10.1016/j.theriogenology.2020.03.011

Pereira GM, Heins BJ, Endres MI (2020) Estrous detection with an activity and rumination monitoring system in an organic grazing and a low-input conventional dairy herd. Animal Reproduction Science 221:106553. doi: 10.1016/j.anireprosci.2020.106553

Rispoli LA, Edwards JL, Pohler KG, Russell S, Somiari RI, Payton RR, Schrick FN (2019) Heat-induced hyperthermia impacts the follicular fluid proteome of the periovulatory follicle in lactating dairy cows. Plos One 14 e0227095. doi: 10.1371/journal.pone.0227095

Rodrigues CFM (2014) Historical context of cattle embryo transfer technique in Brazil. Animal Reproduction 11:137-140.

Sheldon IM, Cronin J, Borges A (2011) The postpartum period and dairy cow fertility Part 2: Ovarian function. Livestock 16:20-24. doi: 10.1111/j.2044-3870.2011.00052.x

Sigdel A, Liu L, Abdollahi-Arpanahi R, Aguilar I, Peñagaricano F (2020) Genetic dissection of reproductive performance of dairy cows under heat stress. Animal Genetics 51:511-520. doi: 10.1111/age.12943

Sirotkin AV, Parkanyi V, Pivko J (2021) High temperature impairs rabbit viability, feed consumption, growth and fecundity: examination of endocrine mechanisms. Domestic Animal Endocrinology 74:106478. doi: 10.1016/j.domaniend.2020.106478

Torres E, Mellado M, Leyva C, García JE, Véliz FG, Hernández-Bustamante J (2020) Serum metabolites and body condition score associated with metritis, endometritis, ketosis, and mastitis in Holstein cows. Pesquisa Agropecuária Brasileira 55. doi: 10.1590/s1678-3921.pab2020.v55.01308

Vallejo DA, Londoño JD, Yepes YA, Tamayo V, Mejia AF, Maldonado JG (2019) Pregnancy rates in hair sheep after Ovsynch synchronization and a combined intracervical fixed-time artificial insemination and 10-day mating period. Veterinary World 12:17791783. doi:10.14202/vetworld.2019.1779-1783

Wallage AL, Johnston SD, Lisle AT, Beard L, Lees AM, Collins CW, Gaughan JB (2017) Thermoregulation of the bovine scrotum 1: measurements of free-range animals in a paddock and pen. International Journal of Biometeorology 61:1381-1387. doi: $10.1007 / \mathrm{s} 00484-017-1315-3$

Zaher HA, Alawaash SA, Swelum AA (2020) Effects of season and breed on the reproductive performance of sheep. Journal of Animal Reproduction and Biotechnology 35:149-154. doi: 10.12750/jarb.35.2.149 